\title{
УДК: 378.091.33-028.22
}

https://doi.org/10.33296/2707-0255-8(15)-07

https://orcid.org/0000-0003-1301-2169*

https://orcid.org/0000-0003-1993-5028**

https://orcid.org/0000 -0003-1145-1897***

\author{
ОКСАНА БАРТКІВ* \\ кандидат педагогічних наук, \\ доцент кафедри загальної \\ педагогіки та дошкільної освіти, \\ Східноєвропейський \\ національний університет імені \\ Лесі Українки, м. Луцьк, \\ Україна \\ ЄВГЕНІЯ ДУРМАНЕНКО** \\ кандидат педагогічних наук, \\ доцент кафедри соціальної \\ роботи та педагогіки вищої \\ школи, Східноєвропейський \\ національний університет імені \\ Лесі Українки, м. Луцьк, \\ Україна

\section{ОКСАНА СМАЛЬКО $* * *$} \\ кандидат педагогічних наук, \\ старший викладач кафедри \\ педагогіки, психології \\ та окремих методик, Луцький \\ педагогічний коледж, м. Луцьк, \\ Україна
}

\section{ВІЗУАЛІЗАЦІЯ ЯК ЕФЕКТИВНИЙ МЕТОД ВИВЧЕННЯ СТУДЕНТАМИ ПЕДАГОГІКИ}

Анотація. У статті розкривається ефективність використання методу візуалізації змісту навчального матеріалу з педагогіки. Метою даної статті $\epsilon$ аналіз методів візуалізації змісту навчальної інформації на заняттях 3 педагогіки в ході вивчення теми «Проектні технології навчання». У ході

\footnotetext{
(c) Українська інженерно-педагогічна академія

(C) ГО "Школа адаптивного управління соціально-педагогічними системами»

() Бартків О., Дурманенко Є., Смалько О.
} 
наукового пошуку використано методи аналізу, синтезу, узагальнення, систематизації, моделювання.

Наголошено, що одним із ефективних способів активізації навчальної діяльності студентів $є$ візуалізація навчального матеріалу, активне використання якої в освітньому процесі дозволяє відійти від пасивного сприйняття майбутніми фахівцями змісту до активного оволодіння ним; візуалізація забезпечує інтенсифікацію освітнього процесу, формування й розвиток критичного й візуального мислення студентів.

Візуалізацію визначено як способи унаочненого висвітлення змісту навчального матеріалу в структурованій формі за допомогою схем, таблиць, графів, фреймів тощо, що сприятиме ефективному оволодінню здобувачами освіти системою компетенцій.

У процесі викладання курсу «Педагогіка» в студентів найкраще розвивається активна творчість, критичне мислення, коли використовуються традиційні способи візуалізації змісту навчального матеріалу (блок-схема, граф-схема, логічний ланцюг (послідовність процесів), таблиця та ін.) та новітні (денотатний граф, фрейм, інтелектуальні та стратегічні карти,кластер та ін.). Розкрито способи візуалізації змісту навчального матеріалу з педагогіки (денотатний граф, фрейм, інтелектуальні карти) в ході вивчення теми «Технологія проектного навчання». Запропоновано варіанти візуалізації змісту навчального матеріалу 3 проектної технології навчання за допомогою фрейму, денотатного графу, інтелектуальних карт.

Резюмується, що візуалізація змісту навчального матеріалу 3 педагогіки дозволяє вирішити низку педагогічних завдань, а саме: сприяти інтенсифікації навчання; активізувати навчальну й пізнавальну діяльність студентів; розвивати критичне, креативне та радіантне мислення; дублювати вербальну інформацію образною, встановлюючи причиннонаслідкові зв'язки між педагогічними поняттями й явищами; формувати візуальну грамотність та візуальну культуру.

Ключові слова: візуалізація, методи візуалізації навчального матеріалу, педагогіка, технологія проектного навчання, денотатний граф, кластер, інтелектуальні карти, фрейм.

Вступ. Сучасні вимоги до реформування освіти в Україні вимагають від закладів вищої освіти підготовку компетентних працівників, активних особистостей, здатних до подальшого самовдосконалення, самореалізації, саморозвитку. Виконання окресленого завдання неможливе без переходу 
від знаннєвої парадигми освіти до компетентнісної, яка вимагає пошуку нових форм, методів і засобів активізації пізнавальної діяльності студентів, розвитку розумових, фізичних і духовних здібностей та якостей.

Одним із ефективних способів активізації навчальної діяльності студентів $\epsilon$ візуалізація навчального матеріалу, активне використання якої в освітньому процесі дозволяє відійти від пасивного сприйняття майбутніми фахівцями змісту до активного оволодіння ним. Поряд з цим, візуалізація забезпечує інтенсифікацію освітнього процесу, формування й розвиток критичного й візуального мислення студентів.

Про переваги використання методу візуалізації свідчать статистичні дані Центру політичних студій та аналітики «Ейдос», відповідно яким візуальна інформація краще сприймається, дозволяє швидко та ефективно донести до слухача власні думки, ідеї, судження. Сприйняття візуальної інформації є важливим для людини оскільки:90\% інформації особистість сприймає через зір; 70\% сенсорних рецепторів знаходяться в очах; близько половини нейронів головного мозку людини задіяні в обробці візуальної інформації; на 19\% менше при роботі 3 візуальними даними використовується когнітивна функція мозку, яка відповідає за обробку та аналіз інформації; на 17\% вища продуктивність людини, що працює 3 візуальною інформацією; на 4,5\% краще згадуються деталі візуальної інформації; в 60000 разів швидше сприймається візуальна інформація в порівнянні з текстовою [11].

Аналіз останніх досліджень і публікацій. Візуалізації в освіті присвячено низку праць зарубіжних учених. Так, основи візуалізації подано в наукових доробках К. Гілберта, Д. Райсберга Е. Тафте; практичні поради щодо застосування способів візуалізації висвітлено в працях Б. Ашера, Р. Кроулі, Дж. Мілза, Т. Поплавські Р. Штайнера тощо. Теоретичні основи візуалізації навчальної інформації розкривають такі () Українська інженерно-педагогічна академія (0 го «Школа адаптивного управління сочіально-педагогічними системами» (О) Бартків О., Дурманенко Є., Смалько О. 
відомі українські науковці, як I. Андрощук, С. Аранова, О. Бабич, Л. Білоусова, А. Вербицький, О. Заболотна, Г. Лаврентьєв, Н. Манько, О. Пєскова, О. Семеніхіна та інші.

Психолого-педагогічні дослідження П. Анохіна, Е. Артем'єва, Н. Жинкіна, Д. Поспєлова, А. Смірнова, А. Соколова, В. Якиманської доводять, що візуалізація сприяє більш успішному сприйманню i запам'ятовуванню навчального матеріалу. Поряд з цим, нам не вдалося знайти цілісного дослідження, яке б розкривало особливості використання методів візуалізації змісту навчального матеріалу на заняттях з педагогіки. Як зазначає О. Ігнатюк, під час викладання дисциплін педагогічного блоку у майбутніх фахівців формується уявлення про педагогічну діяльність і практично-процесуальні вміння здійснювати викладацьку діяльність [6]. Тому важливою є візуалізація змісту навчального матеріалу з педагогіки.

Формулювання цілей статті. Мета статті полягає в аналізі методів візуалізації змісту навчальної інформації на заняттях 3 педагогіки в ході вивчення теми «Проектні технології навчання».

Виклад основного матеріалу дослідження. Великий тлумачний словник сучасної української мови розкриває поняття «візуалізація» як процес отримання видимого зображення яких-небудь предметів, явищ, процесів, недоступних для безпосереднього спостереження [5, с. 140]. Британський науковець К. Гілберт під візуалізацією розуміє наочне уявлення про предмет, речовину, абстрактне поняття або явище, яке є продуктом свідомості [12].

Аналіз психолого-педагогічної літератури засвідчив, що візуалізація науковцями розглядається як:

- створення з усної наочної інформації нового об’єкта творчого характеру, який безпосередньо пов'язаний із суттю та змістом навчальнотеоретичного матеріалу (I. Андрощук); 
- процес згортання розумових змістів у наочний образ; будучи сприйнятим, образ може бути розгорнутий і служити опорою адекватних розумових і практичних дій (А. Вербицький);

- цілісне уявлення про поняття, що сприяє більш міцному засвоєнню навчального матеріалу і одночасно розвиває емоційно-ціннісне ставлення до отриманих знань (Н. Бровка).

Г. Лаврентьєв вводить поняття «візуальний навчальний матеріал» i розуміс його, як дидактичний засіб, за допомогою якого зміст навчального матеріалу подається в структурованій естетично організованій візуальній формі і забезпечує ефективне протікання психологічних процесів сприйняття, дозволяє реалізовувати основні дидактичні принципи, сприяє досягненню педагогічних цілей навчання та розвитку [7].

Оскільки візуалізація навчального матеріалу пов'язана 3 його ущільненням, то від візуалізацією будемо розуміти способи унаочненого висвітлення змісту навчального матеріалу в структурованій формі за допомогою схем, таблиць, графів, фреймів тощо, що сприятиме ефективному оволодінню здобувачами освіти системою компетенцій.

На сьогодні поширеними формами візуалізації навчальної інформації є:

- лист опорних сигналів (короткий умовний конспект, який являє собою наочну конструкцію, що замінює систему фактів, понять, ідей як взаємопов'язаних елементів цілої частини навчального матеріалу);

- структурно-логічні схеми (блок-схеми, граф-схеми, логічні ланцюги (послідовність процесів);

- таблиця (графічна форма представлення кількісних показників або текстового матеріалу у максимально лаконічній, ущільненій формі);

- логіко-смислова модель (дозволяє одночасно побачити всю тему в цілому і кожен їі елемент окремо; 
- здійснити порівняльну характеристику двох явищ, подій, встановити причинно-наслідковий зв’язок, виявити основну проблему і знайти їі рішення) [1, с. 65].

Варто зазначити, що окрім традиційних часто використовуються різні новітні способи візуалізації навчального матеріалу (рис.1.).

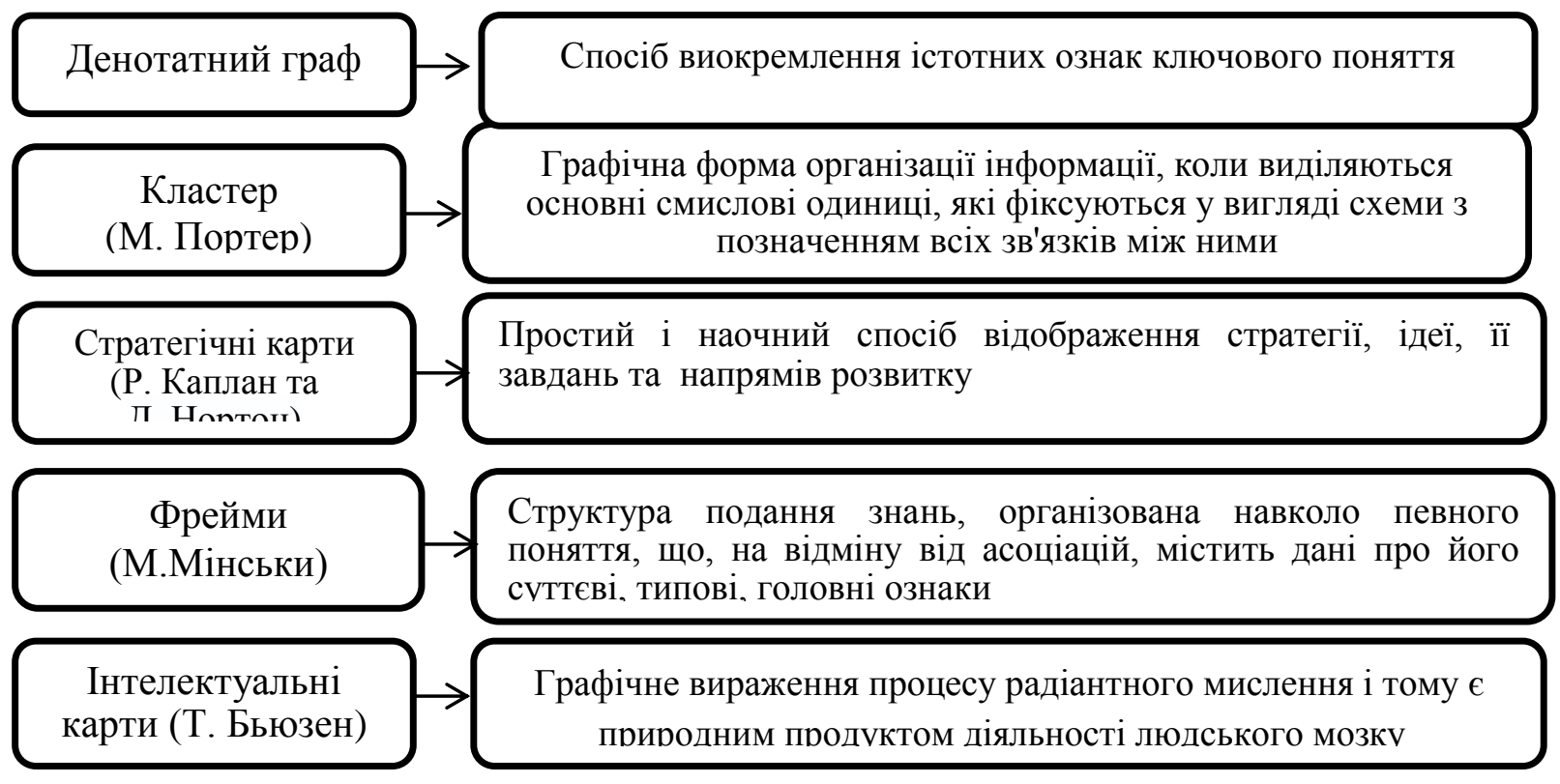

Рис.1. Новітні способи візуалізації змісту навчального матеріалу

Досвід викладання курсу «Педагогіка» засвідчив, що в студентів найкраще розвивається активна творчість, критичне мислення, коли використовуються блок-схеми, граф-схеми, логічні ланцюги (послідовність процесів), таблиці, графи, фрейми, інтелектуальні карти тощо.

Зупинимося на аналізі окремих новітніх способів візуалізації змісту навчального матеріалу в ході вивчення теми «Проектні технології навчання». Варто наголосити, що технологія проектного навчання (метод проектів, проектне навчання) випливає 3 ідеї проблемного навчання та грунтується на розробці і створенні студентом під контролем викладача нових продуктів, що характеризуються суб’єктивною або об’єктивною новизною та практичним значенням [10]. 
У проектному навчанні проявляється раціональне сполучення теоретичних знань і практичних дій при вирішенні конкретної проблеми, використовується сукупність проблемних, дослідницьких, практичних методів роботи, за своєю сутністю завжди творчих [10].

На сьогодні вченими проектне навчання розглядається як (рис.2):

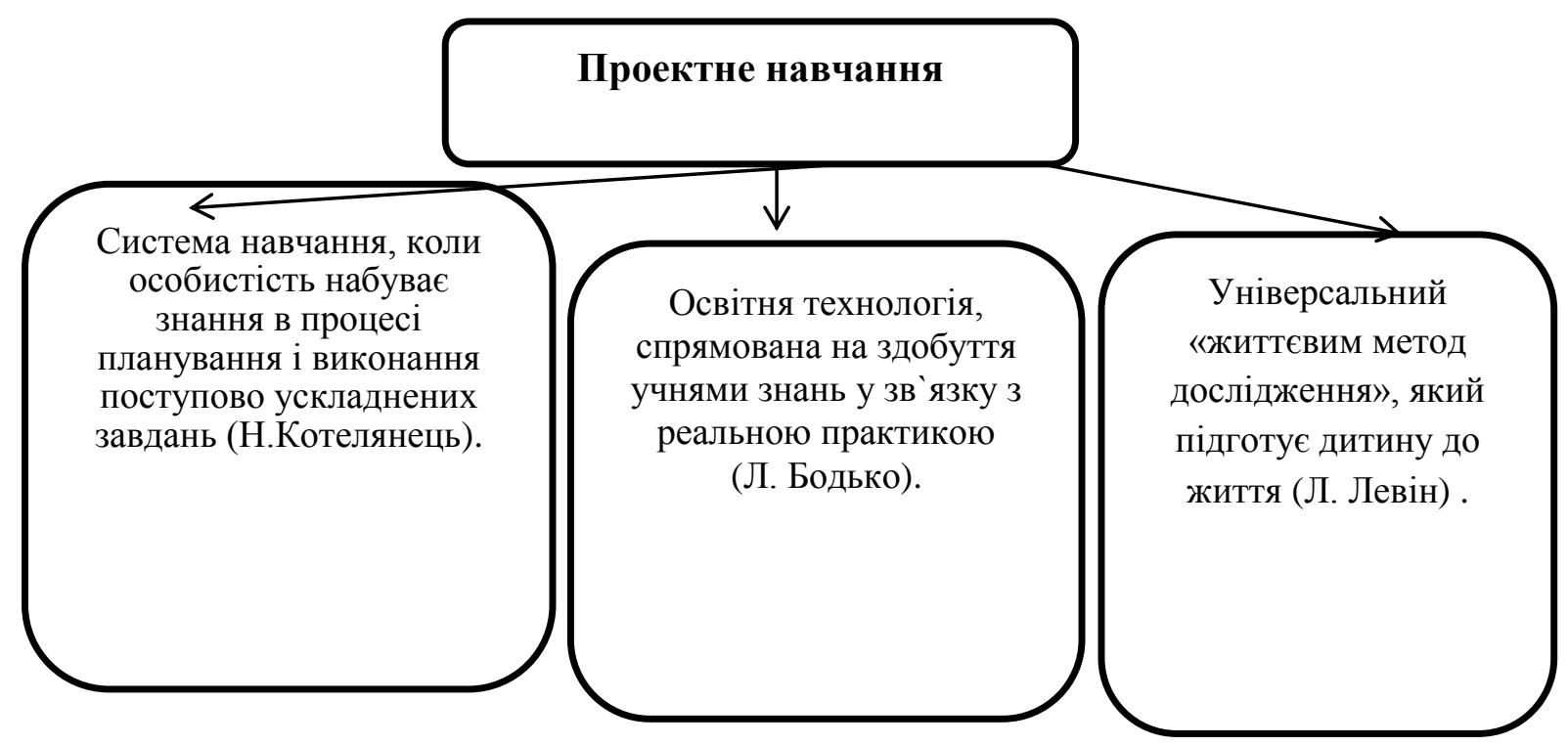

\section{Рис. 2. Підходи вчених до розгляду проектного навчання}

Цікавим у ході вивчення теми $є$ метод візуалізації - фрейм. У психолого-педагогічній науці фрейм розглядається як структура подання знань, організована навколо певного поняття, що, на відміну від асоціацій, містить дані про його суттєві, типові, головні ознаки. На основі поглядів вчених (Л. Волошко, Р. Гуріна) фрейм визначено як схематичну (графічну, табличну) репрезентацію за родово-видовою залежністю певного явища (факту, об'єкта чи процесу), що уможливлює стисло подати значний за обсягом зміст навчального матеріалу [3].

3 метою перевірки знання студентами видів пропонуємо студентам заповнити фрейм видів проектів (Рис.3).

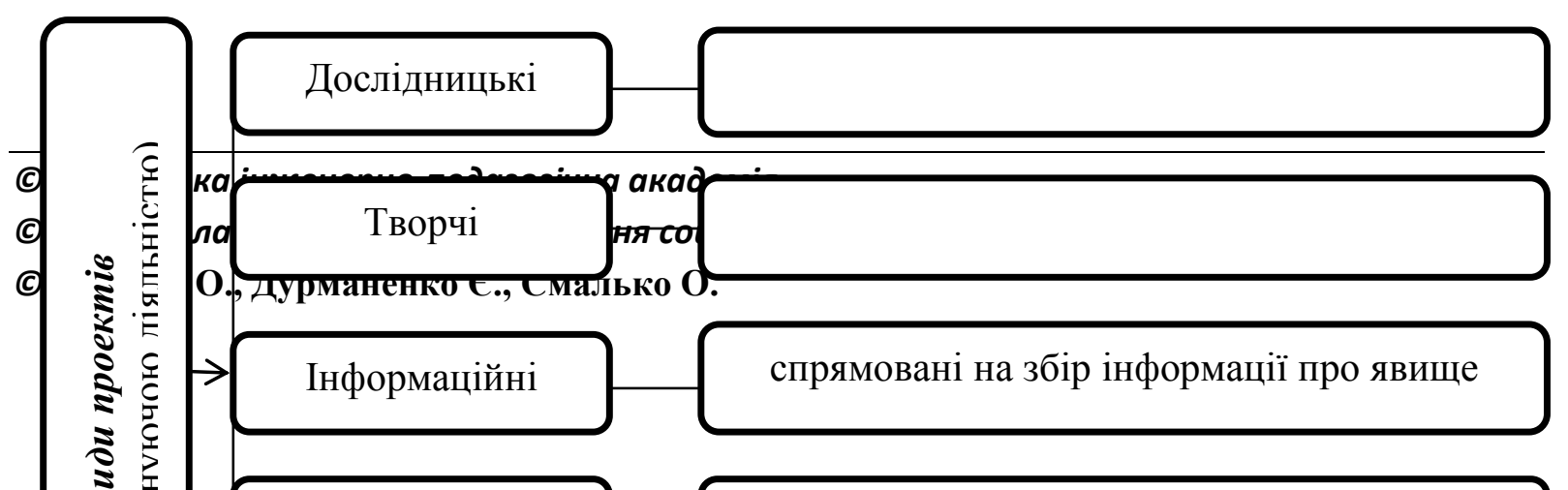




\section{Рис.3. Заповнення фрейму видів проектів}

У процесі заповнення фрейму студенти мають продемонструвати сформованість компетенцій видів проектів, сутності кожного 3 видів, встановити взаємозв’язки між видом проекту й його характеристикою.

3 метою систематизації знань про роль i значення проектного навчання застосовуємо денотатний граф (від лат. denoto - позначаю) система денотатів, пов'язана певними відносинами - це концепція розкладання цілого на частини, декомпозиція терміна на поняття, встановлення зв’язків між частинами і цілим (впорядкування понять) [5].

Денотатний граф складається зверху вниз. Спочатку виділяємо ключове слово, на основі якого будуємо структуру графа. Наступним етапом є підбір дієслів, які зв’язуватимуть ключове поняття й його ознаки.

В. Овдійчук пропонує використовувати такі групи дієслів:

- які вказують на мету - направляти, припускати, наводити, давати;

- які означають процес досягнення результату - досягати, здійснювати;

- які вказують на передумови досягнення результату - грунтуватися, опиратися, базуватися;

\footnotetext{
(c) Українська інженерно-педагогічна академія (c) ГО «Школа адаптивного управління соціально-педагогічними системами» () Бартків О., Дурманенко Є., Смалько О.
} 
- дієслова-зв'язки, за допомогою яких здійснюється вихід на визначення поняття [8].

Третій етап передбачає підбір істотних ознак ключового поняття, які зв’язуються з ним через обрані дієслова. Для кожного дієслова потрібно знайти одну-три ознаки.

Так, у ході вивчення теми 3 педагогіки «Проектне навчання», можемо «ущільнити» зміст навчального матеріалу, застосувавши такий денотатний граф (рис.4)

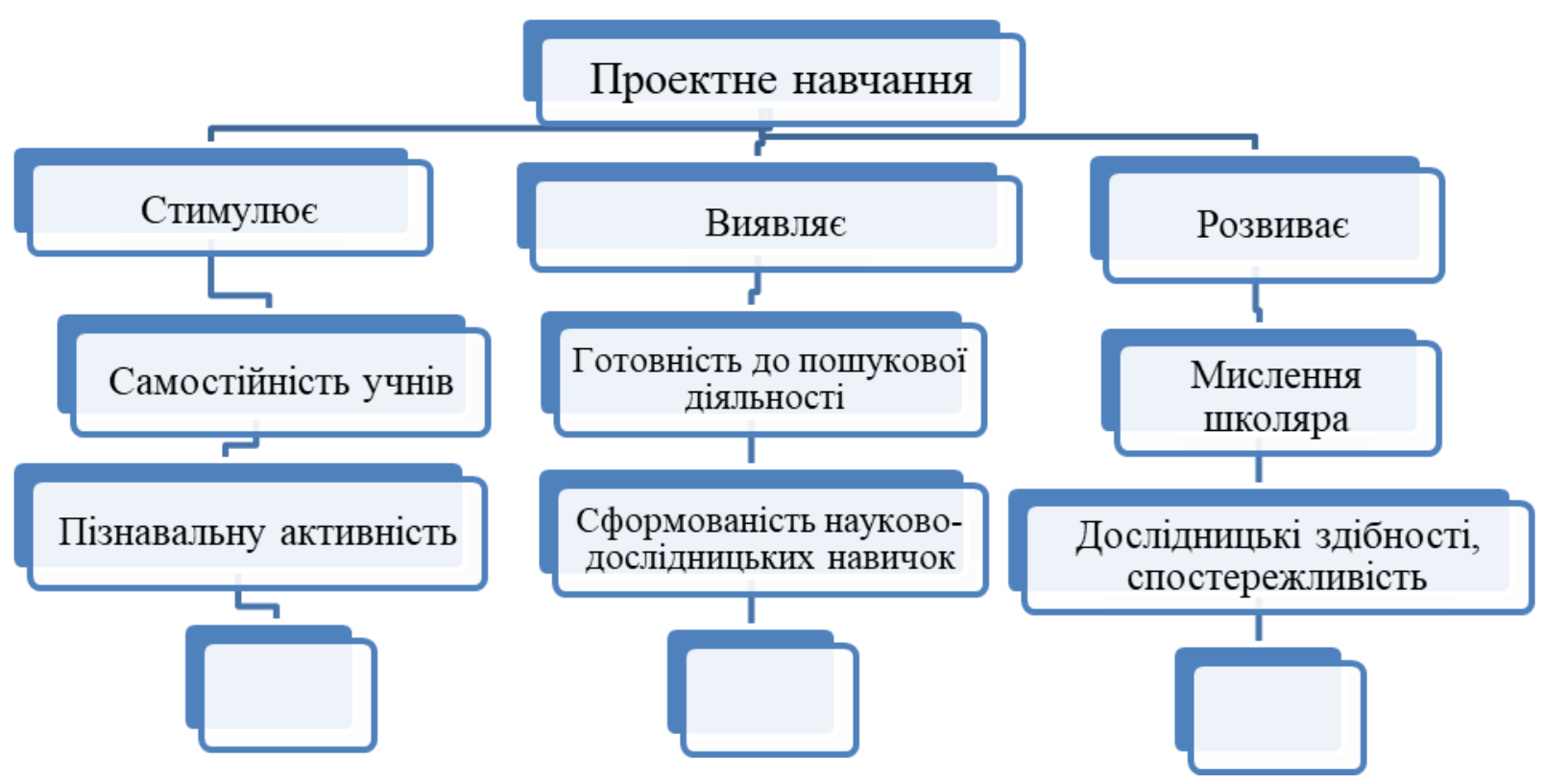

Рис. 4. Денотантний граф «Проектне навчання»

Працюючи 3 поданим денотантним графом студенти демонструють здатність аналізувати технологію проектного навчання, підбирати істотні ознаки ключового поняття «проектне навчання», які зв'язуються 3 ним через обрані дієслова: стимулює, виявляє, розвиває. Можемо запропонувати майбутнім педагогам у ході вивчення теми «Технологія проектного навчання» побудувати інший денотантний граф, підбираючи інші дієслова й іменники.

Розглядаючи етапи проектного навчання можемо застосувати метод візуалізації - інтелектуальні карти (рис.5).
(C) Українська інженерно-педагогічна академія
(C) ГО "Школа адаптивного управління соціально-педагогічними системами»
(ㄱ Бартків О., Дурманенко Є., Смалько О. 


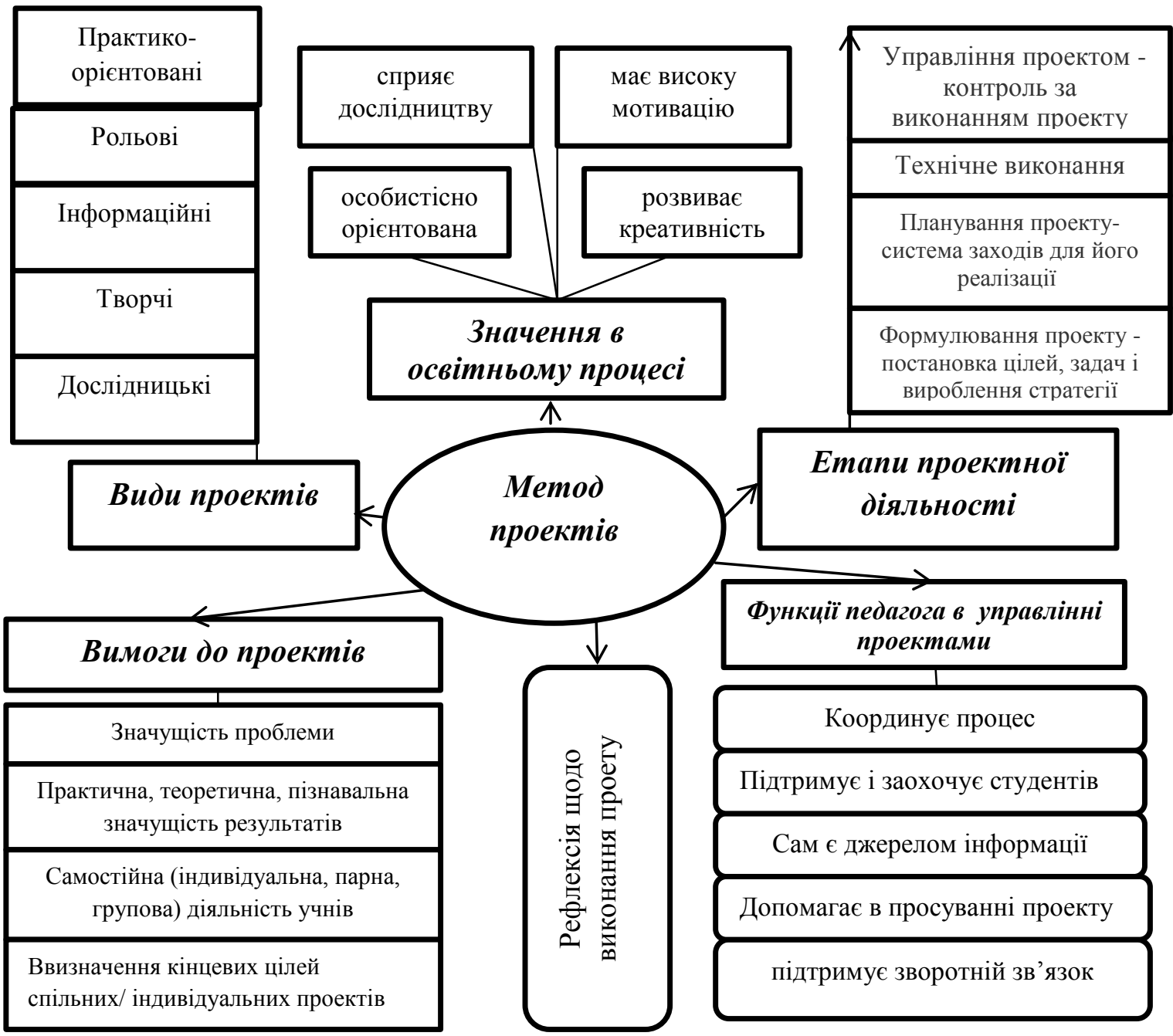

\title{
Рис. 5. Інтелектуальна карта з теми « Метод проектів»
}

Суть методу інтелектуальних карт (майндмеппінг - від англ. Mind maps) полягає в тому, щоб пов’язати окремі елементи асоціативними зв’язками, найбільш звичними саме для людського мислення і пам’яті [1, с.57]. Дослідники також у своїй спільній праці наводять чотири унікальні особливості інтелектуальних карт: об`єкт вивчення представлений у центрі уваги; основні ідеї, завдання чи поняття, пов“язані 3 центральним об’єктом, розходяться від нього у вигляді гілок; гілки (позначаються плавними лініями) пояснюються ключовими словами чи

\author{
(ㄱ) Українська інженерно-педагогічна академія \\ (C) ГО «Школа адаптивного управління соціально-педагогічними системами» \\ () Бартків О., Дурманенко Є., Смалько О.
}


образами; гілки, що відходять від головних, називаються вторинними і т.д.; усі гілки формують взаємопов'язану вузлову систему [4].

Т. Олійник наголошує, що у ході роботи студентів 3 інтелекткартами (ментальні карти) формуються необхідні їм предметні компетентності, зокрема інформаційна, логічна, просторова, хронологічна, аналітична, критичне мислення тощо. Інтелект-карти допомагають оптимізувати всю роботу і зробити іiі не тільки більш ефективною, а й захопливою. Складання ментальних карт $є$ абсолютно самостійною, творчою роботою самого студента. Завдання викладача полягає в інструктажі щодо прийомів створення чи вдосконалення інтелект-карт, не нав'язуючи власні зразки [9]. Підготовка до заняття з використанням методу інтелектуальних карт має включати наступні етапи:1. Вибір теми, презентація майндмеппінгу. 2. Виклад матеріалу заняття.3. Визначення ключових понять та термінів. 4. Об’єднання в групи, розподіл завдань щодо формування карти знань. 5. Презентація інтелект-карт [9, с. 68].

Отже, завдання викладача в процесі викладання педагогіки, як навчального предмета, використовуючи різні методи візуалізації, складне і незрозуміле зробити простим і зрозумілим, громіздке - компактним, тривале - лаконічним, фрагментальне - цілим.

Висновки. Перспективи подальших розвідок напряму. Таким чином, візуалізація змісту навчального матеріалу з педагогіки дозволяє вирішити низку педагогічних завдань, а саме: сприяти інтенсифікації навчання; активізувати навчальну й пізнавальну діяльність студентів; розвивати критичне, креативне та радіантне мислення; дублювати вербальну інформацію образною, встановлюючи причинно-наслідкові зв'язки між педагогічними поняттями й явищами; формувати візуальну грамотність та візуальну культуру.

(C) Українська інженерно-педагогічна академія (c) Го «Школа адаптивного управління соціально-педагогічними системами» () Бартків О., Дурманенко Є., Смалько О. 
Проведене дослідження не претендує на вичерпний розгляд проблеми, подальшого дослідження потребують питання застосування різних методів візуалізації навчальної інформацію в ході вивчення інших тем з педагогіки та визначення вимог до їх використання.

\section{Використана література}

1. Андрощук I. В. Візуалізація навчальної інформації під час викладання дисципліни «Педагогічна майстерність». Психологопедагогічні проблеми сільської школи. Умань, 2011. Вип. 37. С. 62-70.

2. Бабич О. Візуалізація інформації в процесі навчання. Фізикоматематична освіта. № 1(5), 2013. С. 167-170.

3. Бартків О.С. Фреймовий підхід при вивченні теми «Соціальнопедагогічна робота 3 дітьми з розладами аутистичного спектра. Науковий вісник Сумського державного педагогічного університету імені А. С. Макаренка. Серія "«Педагогічні науки: теорія, історія, інновачійні технологіï». 2019. № 2. С. 204-216. $304 \mathrm{c}$.

4. Бьюзен Т. Б. Супермышление. Москва : ООО. Попурри, 2003.

5. Великий тлумачний словник сучасної української мови : 250000 Київ.2005. 1728 с.

6. Ігнатюк Ольга Моделювання викладання педагогічних дисциплін у процесі підготовки майбутніх докторів філософії в умовах технічного університету. Електронне наукове фахове видання «Адаптивне $у$ правління: теорія і практика». Серія «Педагогіка». 6.(11), 2019.

7. Лаврентьев Г. В. Лаврентьева Н. Б., Неудахина Н. А. Инновационные обучающие технологии в профессиональной подготовке специалистов:

http://www2.asu.ru/cppkp/index.files/ucheb.files/innov/Part2/index.html

8. Овдійчук В.А. Розвиток критичного мислення на уроках інформатики в закладі загальної середньої освіти URL: https://zenodo.org.

9. Олійник Т. А. Застосування технології картування мислення (майндмеппінгу) на уроках хімії старшої профільної школи. Таврійський вісник освіти. 2015. № 2(50). С. 63-69.

10. Селевко Г.К. Энциклопедия образовательных технологий. Москва, 2006.816 с.

11. Як і для чого використовувати візуалізацію даних? Ейдос, цент $\mathrm{p}$ політичних студій та аналітики URL: http://eidos.org.ua/novyny/yak-i-dlyachoho-vykorystovuvaty-vizualizatsiyu-danyh/

(c) Українська інженерно-педагогічна академія

(c) ГО «Школа адаптивного управління соціально-педагогічними системами»

(C) Бартків О., Дурманенко Є., Смалько О. 
12. Gilbert K. Visualization in Science Education.Dordrecht: Springer, 2005. 354 p.

\section{REFERENCES}

1.Androshchuk I. V. Vizualizatsiia navchalnoi informatsii pid chas vykladannia dystsypliny «Pedahohichna maisternist». Psykholoho-pedahohichni problemy silskoi shkoly. Uman, 2011. Vyp. 37. S. 62-70.

2. Babych O. Vizualizatsiia informatsii v protsesi navchannia. Fizykomatematychna osvita. № 1(5), 2013. S. 167-170.

3. Bartkiv O.S. Freimovyi pidkhid pry vyvchenni temy «Sotsialnopedahohichna robota $\mathrm{z}$ ditmy $\mathrm{z}$ rozladamy autystychnoho spektra. Naukovyi visnyk Sumskoho derzhavnoho pedahohichnoho universytetu imeni A. S. Makarenka. Seriia "«Pedahohichni nauky: teoriia, istoriia, innovatsiini tekhnolohii». 2019. № 2. S. 204-216.

4. Biuzen T. B. Supermushlenye. Moskva : OOO. Popurry, 2003. 304 s.

5. Velykyi tlumachnyi slovnyk suchasnoi ukrainskoi movy : 250000 Kyiv.2005. $1728 \mathrm{~s}$.

6. Ihnatiuk O. Modeliuvannia vykladannia pedahohichnykh dystsyplin $\mathrm{u}$ protsesi pidhotovky maibutnikh doktoriv filosofii $\mathrm{v}$ umovakh tekhnichnoho universytetu. Elektronne naukove fakhove vydannia "Adaptyvne u pravlinnia: teoriia i praktyka». Seriia «Pedahohika». 6.(11), 2019.

7. Lavrentev H. V., Lavrenteva N. B., Neudakhyna N. A. Ynnovatsyonnыe obuchaiushchye tekhnolohyy $\mathrm{v}$ professyonalnoi podhotovke spetsyalystov: http://www2.asu.ru/cppkp/index.files/ucheb.files/innov/Part2/index.html

8. Ovdiichuk V.A. Rozvytok krytychnoho myslennia na urokakh informatyky v zakladi zahalnoi serednoi osvity URL: https://zenodo.org.

9. Oliinyk T. A. Zastosuvannia tekhnolohii kartuvannia myslennia (maindmeppinhu) na urokakh khimii starshoi profilnoi shkoly. Tavriiskyi visnyk osvity. 2015. № 2(50). S. 63-69.

10. Selevko H.K. Эntsyklopedyia obrazovatelnыkh tekhnolohyi. Moskva, $2006.816 \mathrm{~s}$.

11. Iak i dlia choho vykorystovuvaty vizualizatsiiu danykh? Eidos, tsent $r$ politychnykh studii ta analityky URL: http://eidos.org.ua/novyny/yak-idlya-choho-vykorystovuvaty-vizualizatsiyu-danyh/

12. Gilbert K. Visualization in Science Education.Dordrecht: Springer, 2005. 354 p.

\section{ОКСАНА БАРТКИВ *}


кандидат педагогических наук, доцент кафедры общей педагогики и дошкольного образования, Восточноевропейский национальный университет имени Леси Украинки., г. Луцк, Украина

\section{ЕВГЕНИЯ ДУРМАНЕНКО **}

кандидат педагогических наук, доцент кафедры социальной работы и педагогики высшей школы, Восточноевропейский национальный

университет имени Леси Украинки, г. Луцк, Украина

\section{ОКСАНА СМАЛЬКО $* * *$}

кандидат педагогических наук, старший преподаватель кафедры педагогики, психологи и отдельных методик, Луцкий педагогический колледж, г. Луцк, Украина

\section{ВИЗУАЛИЗАЦИЯ КАК ЭФФЕКТИВНЫЙ МЕТОД ИЗУЧЕНИЯ СТУДЕНТАМИ ПЕДАГОГИКИ}

Аннотация. В статье раскрывается эффективность использования методов визуализации содержания учебного материала по педагогике. Целью статьи является анализ методов визуализации содержания учебной информации на занятиях по педагогике в процес се изучения темы «Проектные технологии обучения» В процессе научного поиска использованы методы анализа, синтеза, обобщения, систематизации, моделирования. Визуализацию определяем как способы візуального представления содержания учебного материала в структурированной форме с помощью схем, таблиц, графов, фреймов и т.П.,что способствует эффективному овладению студентами системой компетенций. В процессе преподавания курса «Педагогика» у студентов лучше развивается активное творчество, критическое мышление, когда используются традиционные способы визуализации содержания учебного материала (блок-схема, графсхема, логическую цепь (последовательность действий), таблица и др.) и новейшие (денотатний граф, фрейм, интеллектуальные и стратегические карты, кластер и др.

Раскрыты методы визуализации содержания педагогики (денотатний граф, фрейм, интеллектуальные карты) в процес се изучения темы «Технологии проектного обучения». Предложены варианты визуализации содержания учебного материала по проектной технологии обучения с помощью фрейма, денотатного графа, интеллектуальных карт.

Резюмируется, что визуализация содержания учебного материала по педагогике позволяет решить ряд педагогических задач, а именно: способствовать интенсификации обучения; активизировать учебную и познавательную деятельность студентов; развивать критическое, креативное и радиантное мышления; дублировать вербальную
(C) Українська інженерно-педагогічна академія
(c) Го «Школа адаптивного управління соціально-педагогічними системами»

(ㄱ Бартків О., Дурманенко Є., Смалько О. 
информацию образной, устанавливая причинно-следственные связи между педагогическими понятиями и явлениями; формировать визуальную грамотность и визуальную культуру.

Ключевые слова: визуализация, методы визуализации учебного материала, педагогика, технологи проектного обучения, денотатний граф, кластер, интеллектуальные карты, фрейм.

\section{OKSANA BARTKIV*,}

$\mathrm{PhD}$ in Pedagogical Science, Associate Professor, Department of General Pedagogy and Preschool Education, East-European National University Named after Lesya Ukrainka, Lytsk

\section{EVHENIYA DURMANENKO**,}

$\mathrm{PhD}$ in Pedagogical Science, Associate Professor, Department of Social Work and Higher School Pedagogy, East-European National University Named after

Lesya Ukraink

\section{OKSANA SMALKO $* * *$,}

$\mathrm{PhD}$ in Pedagogical Science, Teacher at the Department of Pedagogy, Psychology and Selected Methods of Lutsk Pedagogical College.

Abstract. In the article reveals the effectiveness of using the method of visualization of the content of educational material in pedagogy.

The aim of this article is an analysis of methods of visualizing the content of educational information in pedagogical classes during the study of the topic "Project Learning Technologies". During a scientific search the methods of analysis, synthesis, generalization, systematization, modeling are used.

It is emphasized, that one of the effective ways of activating students' educational activity is visualization of educational material, the active use of which in the educational process allows to move away from the passive perception of the content by the future specialists to the active mastery of it; visualization provides intensification of the educational process, formation and development of students' critical and visual thinking.

Visualization is defined as ways of clearly covering the content of educational material in a structured form by means of diagrams, tables, graphs, frames, etc., which will contribute to the effective acquisition of the system of competences by the acquirers of education.

In the process of teaching of course "Pedagogy" students are best developed active creativity, critical thinking, when using traditional ways of visualizing the content of educational material (flowchart, graph diagram, logical circuit (sequence of processes), table, etc.) and the newest (denotation) graph, frame, intellectual and strategic maps, cluster, etc.). The ways of visualization of the content of educational material on pedagogy (denotation 
graph, frame, intellectual maps) in the course of studying the topic "Technology of project training" are revealed. The variants of visualization of the content of the educational material on the project technology of training with the help of a frame, a denotation graph, and intellectual maps are offered.

Summed up, that visualization of the content of educational material on pedagogy allows to solve a number of pedagogical tasks, namely: to promote intensification of learning; to activate educational and cognitive activity of students; to develop critical, creative and radiant thinking; duplicate verbal information in a figurative way, establishing causality between pedagogical concepts and phenomena; to shape visual literacy and visual culture.

Key words: visualization, methods of visualization of educational material, pedagogy, technology of project training, denotation graph, cluster, intellectual maps, frame. 